\title{
Settlement patterns of young-of-the-year rockfish among six Oregon estuaries experiencing different levels of human development
}

\author{
Alison D. Dauble ${ }^{1,3, *}$, Scott A. Heppell ${ }^{1}$, Mattias L. Johansson ${ }^{2,4}$ \\ ${ }^{1}$ Oregon State University, Department of Fisheries and Wildlife, Corvallis, Oregon 97331, USA \\ ${ }^{2}$ Oregon State University, Coastal Oregon Marine Experiment Station, Hatfield Marine Science Center, Newport, \\ Oregon 97365, USA
}

${ }^{3}$ Present address: Oregon Department of Fish and Wildlife, Marine Resources Program, Newport, Oregon 97365, USA

${ }^{4}$ Present address: Department of Biological Sciences, University of Wisconsin - Milwaukee, Milwaukee, Wisconsin 53201, USA

\begin{abstract}
In the US Pacific Northwest, rockfishes Sebastes spp. have recently become a focus for increased management efforts; several species are currently managed under extreme conservation measures due to low population levels and intense fishing pressure. Rockfish recruitment is extremely variable, and a better understanding of the factors influencing recruitment and settlement would assist in prioritizing management and conservation efforts. The goal of this study was to investigate natural and anthropogenic influences on the estuarine settlement process of rockfishes, with a focus on black rockfish $S$. melanops. Trap surveys conducted in 6 Oregon estuaries indicate that young-of-the-year (YOY; Age-0) rockfish utilize multiple Oregon estuaries from spring through late fall. As shown by late season increases in catch rates and the capture of multiple Age-1 individuals, rockfishes may be present in highly developed estuaries through their first winter. Genetic identification confirms that the majority of the YOY rockfish captured during this study were black rockfish S. melanops. Catches were higher in the more developed estuaries, suggesting that the continued development of Oregon estuaries may not adversely affect the rockfish settlement process. This study provides strong evidence of widespread use of estuarine habitat by black rockfish on the Oregon coast during their first year of life, and provides additional support that structure is an important component to the settlement process.
\end{abstract}

KEY WORDS: Sebastes melanops · Larval ecology · Estuarine habitat use · Anthropogenic development

\section{INTRODUCTION}

Estuaries rank among the most productive habitats on earth; however, they are also among the habitats that are most degraded by human activities (Edgar et al. 2000). In the USA, severe eutrophication within Chesapeake Bay has led to massive benthic community-wide mortalities, affecting overall productivity and potentially higher trophic levels within the bay
(Seitz et al. 2009). In the San Francisco estuary, declining pelagic fish abundances have been attributed to human-induced habitat alterations, such as changes in freshwater inputs and reduced turbidity associated with a reduction in the sediment supply and decline of submerged aquatic vegetation (MacNally et al. 2010) and also indirectly through reduced food availability due to exotic species invasions (Sommer et al. 2007). Estuaries are also subject to 
multiple forcing mechanisms from both freshwater and marine influences, and so are particularly vulnerable to climate change impacts (Najjar et al. 2010).

Pacific Northwest estuaries have been moderately developed and exploited within the last century (Borde et al. 2003). Some have jetties and are regularly dredged to allow for deep draft boat traffic, while others maintain a more natural state, with limited shoreline development (Oregon Department of Land Conservation and Development, DLCD 1987). Despite the large number $(>20)$ of estuaries along the Oregon coast, the total estuarine surface area in the state is extremely small, as the majority of individual estuaries are $<30 \mathrm{~km}^{2}$. The few larger estuaries have been substantially altered by anthropogenic development activities (DLCD 1987); however, the vast majority of Oregon estuaries are in a more pristine state, characterized by very little natural or artificial structure (DLCD 1987), making them ideal platforms to explore the effect of the alteration of the estuarine environment through anthropogenic activities.

In general, these small coastal estuaries are highly influenced by the biological and physical characteristics of the nearshore environment (Hickey \& Banas 2003, Miller \& Shanks 2004). The larvae and juveniles of numerous fish species are present in Pacific Northwest estuaries (Pearcy \& Myers 1974, Monaco et al. 1992, Miller \& Shanks 2005), and specific estuarine habitats are considered possible nursery grounds for various marine fishes, particularly English sole Pleuronectes vetulus (Brown 2006, Rooper et al. 2006) and rockfishes of the genus Sebastes (Miller \& Shanks 2004, Gallagher \& Heppell 2010).

Over 100 species of rockfish inhabit the North Pacific Ocean (Hyde \& Vetter 2007) and range from Japan and southeast Asia to the southern tip of Baja California and the Gulf of California (Love et al. 2002). Along the west coast of North America, several species of rockfish are under extreme conservation measures due to low population levels (Parker et al. 2000, Love et al. 2002). The National Marine Fisheries Service has declared 7 species of rockfish overfished within the last decade (Code of Federal Regulations 2011). A species is considered overfished if spawning biomass is found to be less than $25 \%$ of the unfished biomass for groundfish, and rockfishes are considered particularly vulnerable to overexploitation because of their life history characteristics.

Rockfishes are a group of long-lived, slow-growing demersal fishes that give birth to live young (Love et al. 2002). After a pelagic larval stage in off- shore waters of 1 to 6 mo, young-of-the-year (YOY) rockfish move to a relatively shallow benthic environment, a process called settlement (Love et al. 2002). Spatial distribution patterns of YOY rockfishes at this stage are highly complex and likely related to oceanographic conditions (Larson et al. 1994, Wilson et al. 2008), and post-settlement mortality in rockfishes varies in relation to both the number of new recruits and the settling habitat complexity (Johnson 2007). Rockfish recruitment is extremely variable from year to year (Wilson et al. 2008), and there is some evidence that only a small portion of the adult population contributes to the next generation (e.g. as suggested by Hedgecock 1994 in the sweepstakes-chance matching hypothesis; Burford \& Larson 2007, but see Gilbert-Horvath et al. 2006). Information about the early life stages of many rockfish species is patchy and incomplete (Boehlert \& Yamada 1991, Parker et al. 2000, Love et al. 2002).

The black rockfish Sebastes melanops, although not currently listed as an overfished species, constitutes over half of the total recreational groundfish harvest in Oregon (Sampson 2007). Additionally, this species is commercially fished over the majority of the west coast (Parker et al. 2000, Love et al. 2002). Black rockfish are common from southeast Alaska to northern California and are most often found in shallower waters (<55 m; Love et al. 2002). Although black rockfish were not traditionally thought to be found in estuaries (Pearcy \& Myers 1974), this species has recently been shown to utilize the estuarine environment during its early life history (Miller \& Shanks 2004, Gallagher \& Heppell 2010). A better understanding of the factors that affect variability in settlement dynamics, and the role that estuaries play in this process, would be valuable in both prioritizing conservation efforts and enhancing the effectiveness of fisheries management (Beck et al. 2001, Gillanders 2005).

The overall goal of this study was to investigate natural and anthropogenic influences on the estuarine settlement dynamics of black rockfish. Using trap surveys, the specific objectives were to (1) evaluate the variation in settlement patterns of black rockfish in Oregon estuaries that have experienced different levels of anthropogenic development, and (2) estimate the length of time YOY rockfish are present within estuaries and the timing of the initial estuarine settlement pulse. These 2 objectives were evaluated over 2 yr (2008 and 2009) to provide the groundwork for exploring interannual variation in the estuarine settlement dynamics of black rockfish. 


\section{MATERIALS AND METHODS}

\section{Study location}

Six estuaries ( 2 from each of 3 development levels, as defined by the Oregon DLCD 1987) were chosen for this study, and multiple trap surveys were conducted in each of the estuaries over a $2 \mathrm{yr}$ period. The estuaries selected for this study include the Nehalem, Siletz, Yaquina, Alsea, Coos, and Coquille Bays (Fig. 1). Alsea and Siletz Bays are 'conservation' estuaries that lack jetties and have minimal development. Nehalem and Coquille Bays are considered 'shallowdraft development' estuaries that have jetties and a moderate amount of development but are not dredged regularly. Yaquina and Coos Bays are 'deepdraft development' estuaries that have jetties, a substantial amount of shoreline development, and are dredged regularly to admit deep-draft boat traffic.

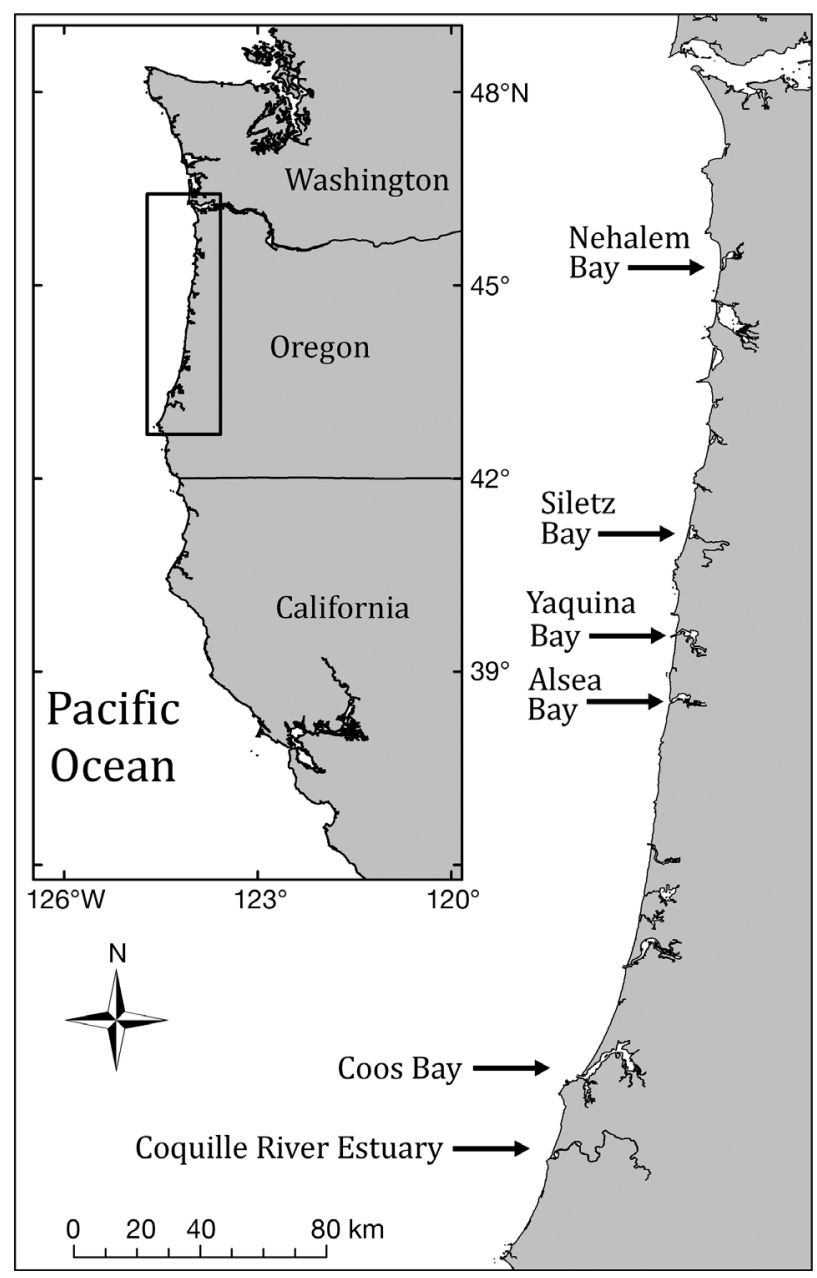

Fig. 1. Locations of the 6 Oregon coast estuaries where trap surveys were conducted
Traps were placed adjacent to existing artificial structures (docks or pilings) or natural structures (rock). Specific trap sites were chosen based on distance from the estuary mouth, accessibility, and the depth of the water at low tide. In 5 of the estuaries (Nehalem, Yaquina, Alsea, Coos, and Coquille), 2 sites were chosen, an 'estuary mouth' site (Site 1), located as close to the mouth of the bay as possible, and an 'upriver' site (Site 2). Upriver sites varied in the distance that they were located from the mouth of the estuary, but an attempt was made to place them approximately halfway up the bay to where the saltwater wedge extends during the summer (thus, the distance from the mouth to the upriver site was greater in larger estuaries). The placement of the upriver traps was also dependent on the availability of structures near the desired location. In Siletz, only 1 site was chosen because of the lack of available upriver hard structures at low tide.

\section{Methodology}

Trapping sessions occurred approximately every 3 to $4 \mathrm{wk}$, from May to November 2008 and April to October 2009. For each individual trapping session, 2 large, square minnow traps (Model MT-10, Aquatic Eco-Systems), approximately $45 \mathrm{~cm}^{2}$ on the base and $30 \mathrm{~cm}$ tall, were fitted with additional weights to prevent movement and then placed at the base of the structure at the trapping site. Traps were set in pairs to increase the probability of catching rockfish. Depth of the traps varied with the tidal cycle and ranged between approximately 1 and $7 \mathrm{~m}$. The traps were set, unbaited, for approximately $24 \mathrm{~h}$ to encompass an entire daily tidal cycle. Temperature $\left({ }^{\circ} \mathrm{C}\right)$, salinity (ppt), and dissolved oxygen $\left(\mathrm{mg} \mathrm{l}^{-1}\right)$ were measured when each pair of traps was deployed and retrieved, using a model YSI-85 multi-meter (YSI). Measurements were taken as close to the traps as possible.

As each trap in the pair was set very close to the other, each trap was not considered an independent measurement, and so the total catch from both traps for each session was summed. In 2008, all fish caught in the traps were identified to species and standard length was measured to the nearest millimeter. In 2009, all fish were identified, but only rockfish were measured. A fin clip was taken from the second dorsal fin of all captured rockfish and stored in $95 \%$ non-denatured ethanol until processed for genetic identification. All live fish were released unharmed, and any in-trap mortalities 
were recorded. Any rockfish that died in the traps were kept and preserved whole in ethanol for later genetic analysis.

\section{Species identification}

All fish collected were identified visually to species, but because of the difficulty associated with identifying YOY rockfish, the visual determinations were confirmed by genetic analysis.

Total genomic DNA was extracted from the dorsal fin tissue using a glass fiber plate extraction protocol (Ivanova et al. 2006). Polymerase chain reaction (PCR) was used to amplify a 782 base pair fragment of the mitochondrial DNA cytochrome $b$ gene using previously published GluRF and CB3RF primers (Rocha-Olivares et al. 1999) and standard protocols. The PCR products were cleaned using a standard ExoSap procedure (USB) and were cycle sequenced using BigDye kits (Applied Biosystems) and internal primers CBInf2 (5'-TRA GKG TTG CAT TGT CTA CTG AGA A-3') and CBInr2 (5'-GGR CTT TAC TAC GGY TCR TAC CT-3'; J. Hyde pers. comm.). Sequencing products were cleaned using a Sephadex filtration protocol (Millipore) and visualized on an ABI 3730XL capillary sequencer. Sequence data were aligned and edited using Sequencher v4.7 (Gene Codes) software.

Using an iterative approach, sample sequences were compared to a reference dataset of 374 independent haplotypes from 67 species of morphologically identified adult Sebastes spp. Species included in the reference dataset are listed in Taylor et al. (2004).

Neighbor-joining trees with nonparametric bootstrapping (1000 replicates), implemented in PAUP* v4b10 (Sinauer Associates), were used to cluster each unknown haplotype within the reference dataset of 374 known adult haplotypes. If an individual clustered within a monophyletic single-species clade with a bootstrap value $>70 \%$, this was accepted as positive identification of the individual. If an individual clustered with a monophyletic clade with a bootstrap $<70 \%$, a secondary analysis was performed that included haplotypes of the 3 nearest (in uncorrected ' $p$ ' genetic distance) species to the unknown rockfish haplotype to confirm the identification. Since many of the species in the reference database are defined by relatively few sequence differences, and bootstrap sampling results in the loss of some data in each iteration, the $70 \%$ cutoff represents a realistic level of support to expect for species-level clades based on cytochrome $b$ data in rockfishes. Some species in the reference dataset (Sebastes wilsoni / emphaeus / variegatus / zacentrus, referred to here as the WEVZ complex, and $S$. melanops / flavidus / serranoides, referred to here as the MFS complex) failed to form monophyletic clades, thus individuals falling within these clades were classified as belonging to the complex rather than to a specific species.

\section{Analysis}

Data were maintained in Microsoft Excel ${ }^{\mathrm{TM}}$ and converted for analysis in R (www.r-project.org) software package. The count of rockfish catches was used for analysis. Catch per unit effort measurements were not considered, as trap time varied little throughout the study (mean $=24.02 \mathrm{~h}$; range $=23.96$ to $24.28 \mathrm{~h}$ ).

A generalized linear model (GLM) selection procedure, with error distributions selected based on Akaike's Information Criterion (AIC) scores, was used to determine whether rockfish catches varied by estuary and/or site location (general formula: rockfish count $\approx$ estuary + site). Catches were also compared within the trap season. GLMs were utilized to assess changes in rockfish catches by month. Additionally, the seasonal timeframe when YOY rockfish were present was divided approximately at the halfway point (15 July; rockfishes captured approximately mid-April to mid-October). GLMs were also used to compare catches between the early and late seasons that included all estuaries and all sites (general formula: rockfish count $\approx$ estuary + site + early versus late season). The $2 \mathrm{yr}$ of data were combined for these analyses, and year of capture was evaluated as an additional explanatory variable in the selection procedures.

Two quantitative proxies for estuary development level were created, called 'hardened linear shoreline' and 'mouth cross-sectional area' (Table 1). These 2 measurements were designed as integrative measures to describe the amount of available structure, the size of the estuaries, the presence of jetties, dredging, and river flow rates. However, these measures are not independent and were therefore used in separate analyses.

Hardened linear shoreline (in $\mathrm{km}$ ) was estimated using the 'ruler' measurement tool in Google Earth $^{\mathrm{TM}}$. Linear segments of bank edge containing hardened shoreline or structure were estimated 3 times per estuary, and then averaged for each estu- 
Table 1. Qualitative and quantitative characteristics of each of the 6 estuaries (from north to south) from the central Oregon coast sampled during this study. Development classification is from DLCD (1987), and the size of the estuary $\left(\mathrm{km}^{2}\right.$ at average high tide) is from Pearcy \& Myers (1974). Average hardened linear shoreline (HLS, $\mathrm{km}$ ) and mouth cross-sectional area $\left(\mathrm{MCA}_{1} \mathrm{~m}^{2}\right.$ ) estimates were collected from a combination of Google Earth ${ }^{\mathrm{TM}}$ software and NOAA navigational charts for the Oregon coast

\begin{tabular}{|llccccr|}
\hline Estuary & $\begin{array}{c}\text { Development } \\
\text { classification }\end{array}$ & $\begin{array}{c}\text { Size of } \\
\text { estuary } \\
\left(\mathrm{km}^{2}\right)\end{array}$ & $\begin{array}{c}\text { Jetties } \\
\text { present? }\end{array}$ & $\begin{array}{c}\text { Channel } \\
\text { dredged? }\end{array}$ & $\begin{array}{c}\text { HLS } \\
\text { estimate } \\
(\mathrm{km})\end{array}$ & $\begin{array}{c}\text { MCA } \\
\text { estimate } \\
\left(\mathrm{m}^{2}\right)\end{array}$ \\
\hline Nehalem & Shallow draft & 9.34 & Yes & No & 2.35 & 1100.3 \\
Siletz & Conservation & 4.8 & No & No & 0.025 & 232.4 \\
Yaquina & Deep draft & 15.82 & Yes & Yes & 8.93 & 3475.2 \\
Alsea & Conservation & 8.68 & No & No & 1.14 & 1019.0 \\
Coos & Deep draft & 44.4 & Yes & Yes & 6.02 & 8482.0 \\
Coquille & Shallow draft & 3.31 & Yes & No & 3.18 & 898.7 \\
\hline
\end{tabular}

\section{RESULTS}

In total, 621 YOY and juvenile rockfish were captured in 2008 in 103 individual trap sessions (mean \pm $\mathrm{SD}=6.7 \pm 1.5$ rockfish session ${ }^{-1}$ ), and 455 were captured in 2009 in 89 individual trap sessions $(4.7 \pm 1.3$ rockfish session ${ }^{-1}$ ). In 2008, YOY rockfish were captured in all 6 estuaries, whereas in 2009, rockfish were captured in all estuaries but Siletz, despite multiple trapping efforts at that location (Table 2). The number of YOY or juvenile rockfish captured during each trap session ranged from 1 to 82 (Fig. 2). Although the fin clips ary. Measurements were made from the estuary mouth to approximately $1 \mathrm{~km}$ past the upriver trapping site for that particular estuary. For Siletz, measurements were made to $1 \mathrm{~km}$ past the single site within that estuary. Mouth cross-sectional area(s) were estimated using the maximum depth published on National Oceanic and Atmospheric Administration nautical charts (Office of Coast Survey, US Department of Commerce, www.charts.noaa.gov) closest to the mouth itself. The width of the mouth was estimated using the Google Earth ${ }^{\mathrm{TM}}$ 'ruler' tool, and the 2 measurements were multiplied to get a cross sectional area (area in $\mathrm{m}^{2}=$ width $\times$ depth). These measures were constructed as proxies and are not meant to be true representations of either hardened linear shoreline or mouth cross-sectional area(s); they are simply meant to provide a reasonable characterization of the human use of the estuary.

Logistic regressions were used to determine the effect of these proxies on the presence of rockfish, after accounting for additional confounding factors. Another GLM selection procedure was used to assess the effect of each of the proxies on the rockfish catch, again using AIC scores to select the most appropriate error distribution. As rockfish were captured at multiple sites within each estuary, site location was accounted for in each of the models. Again, the $2 \mathrm{yr}$ of data were combined for this analysis, and year was evaluated as an additional variable.

Size comparisons between years were made using a $t$-test and excluded YOY captured after 30 September in 2008 and 3 October in 2009 in order to standardize the sampling season between years. Negative binomial distributions were selected for all GLMs, apart from the logistic regressions, for which a binomial distribution were used. taken from each YOY or juvenile rockfish served as a de facto tag, there were no recaptures of previously clipped rockfish during the 2 years of this study.

\section{Genetic identification}

In total, 298 fin clip samples were processed for genetic identification: 248 samples from 2008 and 50 from 2009. Fin clips were separated by estuary and randomly sub-sampled for genetic analysis in proportion to the number of rockfish caught in each estuary. In 2008 (Fig. 3a), 95.2\% ( $=236$ ) of the samples were identified as Sebastes melanops, and in 2009 (Fig. 3b), $86.0 \%$ (n = 43) were S. melanops.

Several individuals of the WEVZ complex (bootstrap: $79 \%)$ were identified in both $2008(1.6 \%, \mathrm{n}=4)$ and $2009(6.0 \%, \mathrm{n}=3)$. Ecological characteristics suggest that the most likely candidate from these 4 is Sebastes emphaeus, the Puget Sound rockfish, as the other 3 species are deepwater rockfishes that are much rarer in shallow waters (Love et al. 2002). In 2008, the WEVZ samples were collected from both Yaquina and Coquille, whereas in 2009, all WEVZ fish were caught in Yaquina Bay.

In 2009, 2 samples (4.0\%) of Sebastes caurinus, the copper rockfish (bootstrap: 79\%), were collected from Yaquina Bay. This species has not previously been reported in this estuary, although it has been found in Coos Bay (Miller \& Shanks 2004). No copper rockfish were identified in 2008. Of the remaining samples, 1 sample from Nehalem (2008) and 2 samples from Yaquina (2009) were identified to the MFS complex (bootstrap: 100\%). S. melanops and S. flavidus have both been previously reported in Yaquina Bay (Gallagher \& Heppell 2010). S. serranoides has 
Table 2. Sebastes spp. Number of trap sessions conducted (with percentage of sessions that caught rockfish in parentheses), number of rockfish that were captured, and dates of the first and last trap sessions where rockfish were captured in each estuary (from north to south) by site and year

\begin{tabular}{|c|c|c|c|c|c|c|c|}
\hline \multirow{2}{*}{ Estuary } & \multirow[t]{2}{*}{ Site } & \multicolumn{3}{|c|}{2008} & \multicolumn{3}{|c|}{2009} \\
\hline & & No. sessions & No. rockfish & Capture dates & No. sessions & No. rockfish & Capture dates \\
\hline \multirow[t]{2}{*}{ Nehalem } & 1 & $7(42.6)$ & 3 & 6 July-13 Nov & $5(20.0)$ & 1 & $25 \mathrm{Aug}$ \\
\hline & 2 & $6(50.0)$ & 18 & 6 July-18 Oct & $3(33.4)$ & 1 & 1 July \\
\hline Siletz & 1 & $8(50.0)$ & 11 & 30 June-26 Aug & $7(0.0)$ & 0 & $\mathrm{n} / \mathrm{a}$ \\
\hline \multirow[t]{2}{*}{ Yaquina } & 1 & $11(63.6)$ & 23 & 9 June-19 Nov & $8(62.5)$ & 112 & 13 May-30 July \\
\hline & 2 & $14(42.9)$ & 40 & $1 \mathrm{May}-19 \mathrm{Nov}$ & 32 (81.3) & 183 & $11 \mathrm{May}-27 \mathrm{Aug}$ \\
\hline \multirow[t]{2}{*}{ Alsea } & 1 & $5(40.0)$ & 3 & 26 Aug-25 Sept & $5(40.0)$ & 4 & 9 June-25 July \\
\hline & 2 & $7(28.6)$ & 2 & 9 July-26 Aug & \multicolumn{3}{|c|}{$\begin{array}{l}\text { Location inundated by sand during } \\
\text { winter of } 2008 / 2009\end{array}$} \\
\hline \multirow[t]{2}{*}{ Coos } & 1 & $6(83.3)$ & 41 & 22 June-22 Nov & $5(60.0)$ & 17 & 29 May-2 Oct \\
\hline & 2 & $7(100.0)$ & 176 & 24 May-22 Nov & $5(100.0)$ & 69 & 17 Apr-2 Oct \\
\hline \multirow[t]{2}{*}{ Coquille } & 1 & $7(71.4)$ & 43 & 24 June-22 Nov & $5(60.0)$ & 9 & 29 May-3 Aug \\
\hline & 2 & $8(62.5)$ & 154 & 24 June-22 Nov & $5(80.0)$ & 14 & 29 May-2 Oct \\
\hline
\end{tabular}

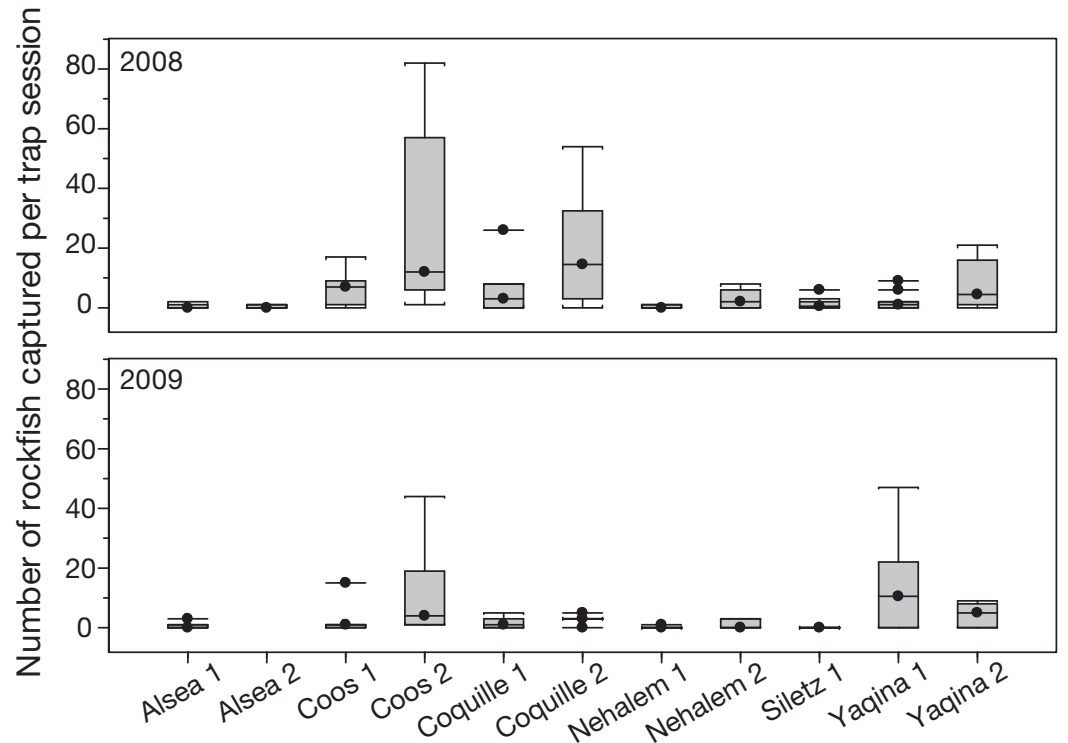

Fig. 2. Number of young-of-the-year/juvenile rockfish Sebastes spp. captured per trap session for each estuary and site in 2008 and 2009

been reported in extremely shallow depths as YOY but not specifically in estuaries (Love et al. 2002).

\section{Development level}

The presence of rockfish was positively associated with estuaries with a higher hardened linear shoreline estimate (logistic regression; $\mathrm{p}=0.002$ ), after accounting for observations at different sites within those estuaries and with both years of data included in the model. The odds of catching a juvenile rockfish increased by $20.1 \%$ for each $\mathrm{km}$ increase in hardened linear shoreline (95\% CI: 17.9 to $22.3 \%$ ). The addition of site to the model did not improve the model fit (AIC = 182 versus 183).

The presence of rockfish in the catch was also positively associated with estuaries with a larger mouth cross-sectional area (logistic regression; $\mathrm{p}=$ 0.001), after accounting for different sampling locations and with both years of data. The odds of catching a juvenile rockfish increased by $31.8 \%$ for each $1 \mathrm{~km}^{2}$ increase in the mouth crosssectional area (95\% CI: 0.7 to $72.4 \%$ ). Again, the addition of site to the model did not substantially improve the model fit (AIC $=179$ versus 180).

Year was not determined to be a significant explanatory variable when investigating the effect of the hardened linear shoreline estimate on rockfish catches $(p=0.26)$. Rockfish catches were higher in estuaries with higher hardened linear shoreline estimates (GLM; p < 0.001 ), after accounting for catches at different sites (model selected: rockfish count $\approx$ hardened linear shoreline/site location, AIC = 702). A similar model (rockfish count $\approx$ hardened linear shoreline + site) improved the model fit $(\mathrm{AIC}=696)$; however, the former model was selected as a more accurate representation of the structure of the data.

Similarly, rockfish catches were also higher in estuaries with larger mouth cross-sectional areas (GLM; $\mathrm{p}<0.001$ ), after accounting for catches at different sites (model selected: rockfish count $\approx$ mouth cross-sectional area/site location, AIC = 705). The addition of site to the model selection procedure did 
a) 2008

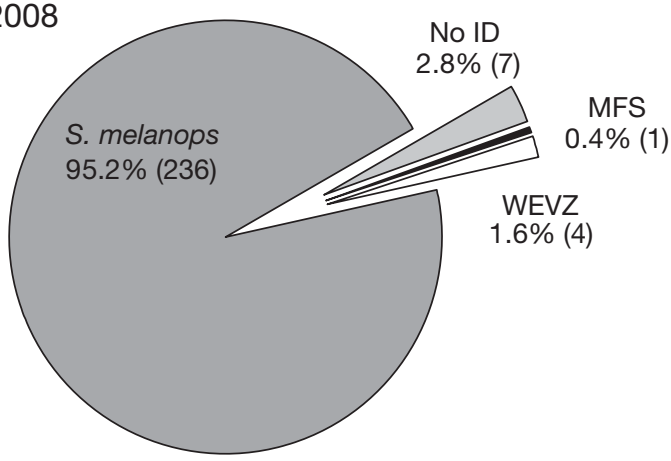

b) 2009

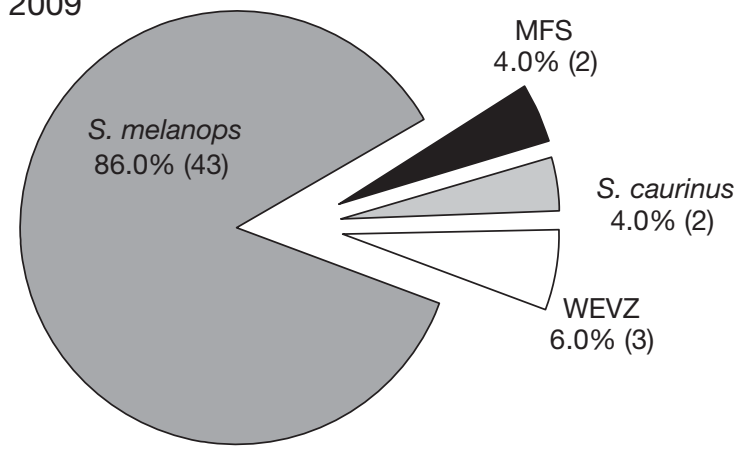

Fig. 3. Proportion and sample size (n) of the genetically identified young-of-the-year rockfishes Sebastes spp. in (a) 2008 $(\mathrm{n}=248)$ and (b) $2009(\mathrm{n}=50)$. The WEVZ complex consists of S. wilsoni / emphaeus / variegatus / zacentrus and the MFS complex consists of $S$. melanops / flavidus serranoides

not improve the model fit (AIC $=706$ ); however, the nested model was selected in order to account for the collection of data in different locations within each estuary. Again, year was not determined to be a significant explanatory variable (model: rockfish count $\approx$ year + mouth cross-sectional area/site location; $\mathrm{p}=0.27$ ).

\section{Spatial comparisons}

There were significant differences in the YOY rockfish catch among all estuaries $\left(G_{L} M_{i} \mathrm{p}<0.001\right)$ and sites (GLM; $\mathrm{p}=0.014$; rockfish count $\approx$ estuary / site). Year was not a significant factor $(p=0.17)$, and the addition of site did improve the model fit slightly (AIC $=678$ versus 682). The interaction between the estuary and site effects was marginally significant ( $p=0.064$ ) but did not improve the model fit (rockfish count $\approx$ estuary $\times$ site; AIC $=678$ ), and was eliminated in favor of the nested version. An additive version of this model (rockfish count $\approx$ estuary + site location) was also eliminated in favor of a slightly lower AIC value, though not significantly different $(\mathrm{AIC}=679)$, and a more representative model.

\section{Intra-seasonal comparisons}

As there were differences found spatially among sampling locations, GLMs for exploring intra-seasonal variation in rockfish catches were constructed to account for this. Model selection procedures for these comparisons used the final model selected for the spatial comparisons (rockfish count $\approx$ estuary/ site), and year was not included as an additional explanatory variable.

The early and late seasons showed marginally significant differences in rockfish catches $(G L M ; p=$ 0.016), after accounting for spatial variation among the estuaries and sites. The model selected (rockfish count $\approx$ estuary / site + early versus late season; $\mathrm{AIC}=$ 675) was significantly improved by the addition of estuary and site (AIC $=713$ ). However, there were also significant differences in the rockfish catches by the month of capture $\left(\mathrm{GLM}_{i} \mathrm{p}<0.001\right)$, after accounting for sampling locations (estuary and site). This model (rockfish count $\approx$ estuary / site + month of capture) was significantly improved by the substitution of month for the early versus late season variable (AIC $=668$ versus 675 ). Taken together, this confirms that there was significant intra-seasonal variation in rockfish catches after accounting for spatial variation.

\section{Size at capture comparisons}

In 2008, YOY and juvenile rockfishes ranged from 22 to $90 \mathrm{~mm}$ standard length $(\mathrm{n}=610$, mean: $60.1 \mathrm{~mm}$ ), and in 2009, rockfish length ranged from

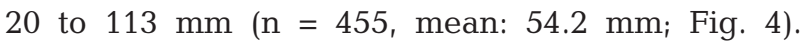
Multiple larger individuals (82 to $113 \mathrm{~mm}$ ) were caught in the early season (April/May) in both 2008 and 2009; these were most likely Age-1 juveniles from the previous year's recruitment. After discarding the late-season captures in 2008 and excluding these probable Age-1 individuals, the average size of YOY rockfishes in 2009 was found to be $5.9 \mathrm{~mm}$ smaller than the 2008 average $(t$-test; $\mathrm{p}<0.001,95 \%$ CI: 4.8 to $7.1 \mathrm{~mm}$ ). Growth rates from YOY black rockfish in Yaquina Bay have been measured at approximately $0.5 \mathrm{~mm} \mathrm{~d}^{-1}$ (Gallagher \& Heppell 2010), but whether the size difference detected in this study is ecologically relevant is unknown. Approximate size at settlement in this study was consistent with other estimates for Sebastes melanops (46 mm; Matarese et al. 1989). A large number of pre-settlement size YOY rockfish ( $\mathrm{n}=67$ individuals $\leq 45 \mathrm{~mm}$ ) were caught in 2009, but few were captured in $2008(\mathrm{n}=9)$. 


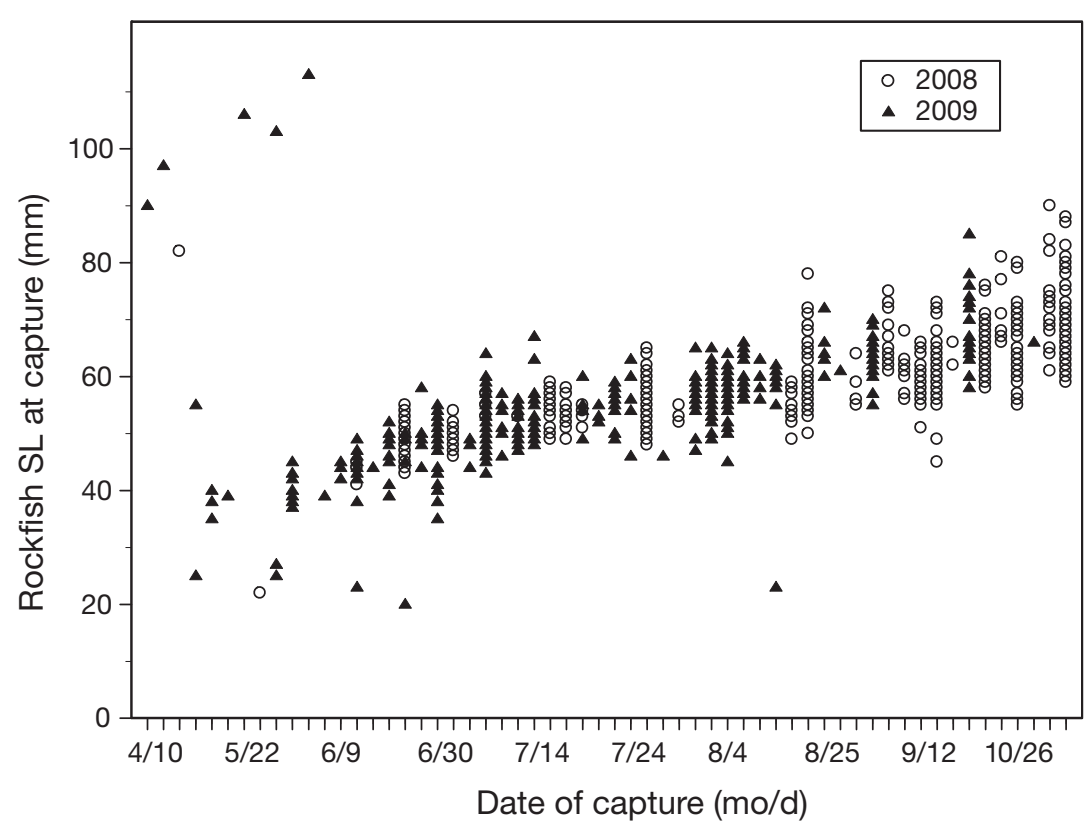

Fig. 4. Size distributions of young-of-the-year rockfish Sebastes spp. (standard length, SL) from all estuaries in 2008 (O) and 2009 (A) breeding, feeding, or growth to maturity' (NOAA Habitat Conservation 2011: www.habitat. noaa.gov/pdf/ magnusonstevensact.pdf). However, Gallagher \& Heppell (2010) only sampled in 1 estuary and the present study confirms the presence of rockfish in multiple other estuaries on the Oregon coast.

The dominant species captured during the present study was Sebastes melanops, which has also been reported as the dominant YOY rockfish species in intertidal pools along the Oregon and northern California coasts (Studebaker \& Mulligan 2008), and in shallow nearshore rocky relief areas (Miller \& Shanks 2004). In comparison, no black rockfish were captured at deeper nearshore reefs, most likely due to the depth $(>35 \mathrm{~m})$ of the reef (Gallagher \& Heppell 2010). This may be indicative of a niche separation during this particular life stage, as

\section{Environmental variables}

Temperature (range for all sites: 8.5 to $16.9^{\circ} \mathrm{C}$ ), salinity (13.8-33.6 ppt), and dissolved oxygen (5.6 to $12.9 \mathrm{mg} \mathrm{l}^{-1}$ ) varied spatially according to the location of the site within the estuaries and the depth of the trap site, but not necessarily on a temporal basis.

\section{DISCUSSION}

In addition to continued documentation of YOY rockfish use of the Coos and Yaquina estuaries, to our knowledge, this is the first documentation of YOY rockfish in Nehalem, Siletz, Alsea, and Coquille estuaries. YOY rockfish have been previously captured in Yaquina (Schlosser \& Bloeser 2006, Gallagher \& Heppell 2010), Coos (Miller \& Shanks 2004, Schlosser \& Bloeser 2006), Winchester, and Tillamook Bays (Appy \& Collson 2000) on the Oregon coast. In spite of the small amount of estuarine habitat on the Oregon coast, the presence of YOY black rockfish within all of these estuaries suggests that they are an essential habitat (as demonstrated by Gallagher \& Heppell 2010) during a black rockfish's first, and possibly, second year. 'Essential fish habitat,' as defined in the Magnuson Stevens Fishery Conservation and Management Act, is considered 'those waters and substrate necessary to fish for spawning, mostly YOY blue rockfish $S$. mystinus were captured on those reefs (Gallagher \& Heppell 2010).

The present study is the first to describe the capture of WEVZ complex YOY rockfish from any estuary. As mentioned previously, the fish identified to the WEVZ complex are most likely the Puget Sound rockfish, due to the shallow depth of the estuary sites. If these samples are indeed Puget Sound rockfish, this is the first documentation of estuarine habitat use by this species outside of Puget Sound (Love et al. 2002). Little is known about the pygmy Sebastes wilsoni, harlequin S. variegatus, and sharpchin $S$. zacentrus rockfishes, but they are generally considered to be rare in nearshore environments, such as estuaries, while the Puget Sound rockfish is common in the Oregon nearshore ocean (Love et al. 2002).

Copper rockfish were found in small numbers and have been previously reported in Yaquina Bay (Appy \& Collson 2000, Schlosser \& Bloeser 2006) but were not found in a study where genetic methods were used to identify species (Gallagher \& Heppell 2010), possibly due to the low frequency of copper rockfish occurrence. Copper rockfish have also been captured in light traps in Coos Bay (Miller \& Shanks 2004), and may be present in the bay as adults (Johansson et al. 2008). The lack of copper rockfish captured in Coos Bay during the present study could be accounted for by differences in sampling frequency or the trap style, or because YOY copper 
rockfish were simply not present in Coos Bay during the timeframe of the study. Given the small numbers of copper rockfish captured during this and other studies, it seems likely that they are simply utilizing estuarine habitats more sporadically than black rockfish.

The increased catch rates of rockfishes within the more developed estuaries lends support to the argument that structure is a vital component of the settlement process (Love et al. 1991, 2002, Buckley 1997) and indicates that increased development projected for the Oregon coast (Kline et al. 2003) would not necessarily lead to increased YOY rockfish mortality, at least during the immediate post-settlement period. In general, structure can reduce post-settlement mortality by providing refuge from predation (Hixon \& Beets 1989, Johnson 2007) and can affect other demographic measurements, such as individual size and community species assemblages (Crowder \& Cooper 1982, Hixon \& Beets 1989). The presence of structure perhaps even triggers the initiation of the settlement process in rockfishes (Carr et al. 2003, Pastén et al. 2003). Human development within estuaries could potentially serve as a mechanism to increase initial post-settlement recruitment of rockfishes, although population-level effects would be difficult to quantify as very few links between abundance of post-settlement rockfishes and overall population trends are currently established (Sakuma et al. 2006, Wilson et al. 2008). The limited amount of structure available in the majority of these estuaries further supports the importance of available habitat during the settlement process for rockfishes.

Of course, an increase in the amount of underwater structure is not the only result of increased estuarine development, and as such, development cannot be considered directly beneficial to rockfish populations. Other anthropogenic impacts such as pollution, introduction of invasive species, and loss and degradation of existing natural habitats within estuaries have caused fundamental alterations to estuarine species compositions and habitat quality (Lotze et al. 2006). With YOY rockfishes spending a greater proportion of the year in the more developed estuaries, as indicated by the results presented (see Tables 1 $\& 2$ ), increased exposure to toxins may also be a concern, as has been demonstrated in salmonids (Arkoosh et al. 1998). Dependence on estuarine environments has been identified as a significant risk factor, and species that use these environments at any life stage are considered to be highly vulnerable (Roberts \& Hawkins 1999). Rockfishes in general are also considered to be particularly susceptible to overfishing due to an inherent low productivity and late age at maturity (Parker et al. 2000) and therefore may be unable to adapt quickly to detrimental conditions that may develop in estuaries.

The mouth cross-sectional area and hardened linear shoreline proxies, created for this study to describe development level, could be applied to other studies examining human impacts on estuarine inhabitants. The estimate of each of the proxies in each estuary was consistent with the classification scheme established by the DLCD (1987), and is fairly representative of the level of development. However, it is important to note that the proxies used here integrate several aspects that may be important for explaining the differences between the catch rates in multiple estuaries. They do not address specific factors such as overall size of the estuary, river flow rates, tidal exchanges, or the types of structure available, but rather attempt to combine these multiple factors into 1 quantifiable variable. As such, the impact of each of these factors individually cannot be assessed using these proxies. However, they do provide a useful starting point for many potential avenues of research on human impacts on estuarine ecosystems and are less intensive compared to existing methods.

In general, differences in rockfish catch among the estuaries lend support to the concept that more developed estuaries may harbor more YOY rockfish; significant differences indicated that more developed estuaries had higher catches than less developed estuaries. Settlement patterns suggest that YOY rockfish are also present for a longer part of the year (>6 mo) in the 2 most developed estuaries (Yaquina and Coos) when compared to the 2 to 3 mo residence times observed in other estuaries. These results suggest that specific estuaries on the Oregon coast may be more important to this early life history stage than others, which could have consequences for conservation and management planning for black rockfish in particular. For example, indices of juvenile abundance could be easily estimated in the estuaries, which may provide useful information on interannual variability in recruitment.

As mentioned, rockfish catches in multiple estuaries were significantly different among sites and appeared to be driven by observed late-season increases in a subset of the estuaries sampled. These observations are supported by the significant intraseasonal differences presented. There are several possible biological explanations; however, this lateseason increase is most likely to be indicative of movement up or down the estuary instead of additional recruitment. This pattern could possibly be 
movement to a more sheltered location within the estuary prior to the winter storm season or as a stopover point on their way out of the bay. If the former is true, this phenomenon is possibly a function of the size of the estuary rather than the level of development or location on the coast. There are also several possible ecological explanations, including temporal shifts in the location of known predators, such as lingcod Ophiodon elongatus or salmon Oncorhynchus spp., within the estuaries. Lingcod are known to use locations near estuary mouths as nesting sites during the winter and early spring months (Love 1996). Salmon have also been shown to predate on YOY rockfishes (Baldwin et al. 2008), and the timing of salmon runs through the estuaries may affect YOY rockfish movement patterns as well. Salmon runs in these 6 estuaries range from spring to late fall, and therefore overlap the time period when YOY or juvenile rockfishes are present. The general size distribution of rockfish did not change at this point in the season, indicating that a second settlement event was unlikely. The physical parameters measured (temperature, salinity, dissolved oxygen) encompassed a wide range of conditions throughout the year, and so factors such as decreased salinity from increased fall river flow were not likely to have affected the spatial distributions of YOY rockfishes.

Although Age-1 rockfish were not specifically targeted, the minnow traps employed (with an opening of approximately $3 \mathrm{~cm}$ by $30 \mathrm{~cm}$ ) caught a fair number of probable Age-1 rockfishes at the beginning of the season in Yaquina and Coos Bays in 2009. This suggests that some portion of the YOY rockfishes do overwinter in the estuary, or at least, move into the estuary from the nearshore environment in the early spring. In either case, older juveniles in addition to the YOYs do appear to use habitats within certain estuaries.

The environmental conditions measured during the course of the present study were not clearly different from the normal conditions encountered in an Oregon estuary, and are likely not driving the relative distribution of YOY rockfish in Oregon estuaries. This was expected, given the number of studies confirming the presence of YOY rockfish within these estuaries and the fact that the present study did not encounter environmental conditions atypical to estuarine environments on the Oregon coast. Results may have differed if environmental conditions were measured on a continuous basis throughout the trap session.

Catches of YOY rockfish in Yaquina Bay were similar to those of Gallagher \& Heppell (2010) in terms of species compositions and timing of capture events, indicating that YOY rockfish have used the estuarine habitat in this bay consistently over multiple years (2004 to 2005, 2008 to 2009). Estuarine habitat within Coos Bay is used by YOY rockfishes on a consistent interannual basis (2000 to 2009) as well (Miller \& Shanks 2004, J. A. Miller pers. comm.). To our knowledge, no other information exists on interannual differences in YOY rockfish presence within other estuaries on the Oregon coast. The trap surveys conducted here establish a baseline for assessing interannual variation in estuarine settlement, although additional information on other factors potentially affecting settlement levels interannually would be needed to fully explore this, and for spatial comparisons across a large portion of the Oregon coast.

Overall, the present study explored settlement patterns of rockfishes on the Oregon coast during a life stage for which little information exists, documented that YOY black rockfish settle into multiple estuaries on the Oregon coast, and provides additional support for the importance of structure during the settlement process. Other studies of north Pacific rockfishes have shown that settlement can be an active process under behavioral control (Pastén et al. 2003) and that habitat complexity could be as important a factor as the initial supply of recruits in post-settlement mortality rates (Johnson 2007). Although annual recruitment in rockfishes is extremely variable (Love et al. 1991, Ralston \& Howard 1995, Wilson et al. 2008), a recent long-term study in California showed positive correlations between newly settled rockfish abundances and year class strength in adult populations (Laidig et al. 2007), so information regarding the post-settlement life stage is valuable to fisheries management efforts. This study has provided evidence supporting the use of estuarine habitat by Sebastes melanops, and possibly other species of rockfish, during their early life history and suggests that the continued development of these habitats could affect population dynamics of marine fish species on the west coast. Future work should focus on continuing to explore the connections between the post-settlement life stage in rockfishes and the exploited adult populations, and how anthropogenic influences could alter this relationship.

Acknowledgements. We thank J. Hyde and C. Vanegas for assistance with the genetic identification work and field assistants S. Jackson and R. Hamner. A. Evans and S. Hilber provided valuable comments on the manuscript. This study was supported in part by Oregon State Wildlife Grant Program grant T-16-1 E-47. Additional support was provided by the Hatfield Marine Science Center. 


\section{LITERATURE CITED}

Appy M, Collson PJ (2000) Oregon coastal juvenile rockfish study. Oregon Department of Fish and Wildlife, Marine Resources Division, Newport, OR

Arkoosh MR, Casillas E, Clemons E, Kagley A, Olson R, Reno P, Stein JE (1998) The effect of pollution on fish diseases: potential impacts on salmonid populations. J Aquat Anim Health 10:182-190

Baldwin RE, Miller TW, Brodeur RD, Jacobson KC (2008) Expanding the foraging history of juvenile Pacific salmon: combining stomach-content and macroparasitecommunity analyses for studying marine diets. J Fish Biol 72:1268-1294

> Beck MW, Heck KL Jr, Able KW, Childers DL and others (2001) The identification, conservation, and management of estuarine and marine nurseries for fish and invertebrates. Bioscience 51:633-641

Boehlert GM, Yamada J (1991) Introduction to the symposium on rockfishes. Environ Biol Fishes 30:9-13

Borde AB, Thom RM, Rumrill S, Miller LM (2003) Geospatial habitat change analysis in Pacific Northwest coastal estuaries. Estuaries 26:1104-1116

Brown JA (2006) Using the chemical composition of otoliths to evaluate the nursery role of estuaries for English sole Pleuronectes vetulus populations. Mar Ecol Prog Ser 306: 269-281

Buckley RM (1997) Substrate associated recruitment of juvenile Sebastes in artificial reef and natural habitats in Puget Sound and the San Juan Archipelago, Washington. Tech Rep RAD97-06. Washington Department of Fish and Wildlife, Olympia, WA

Burford MO, Larson RJ (2007) Genetic heterogeneity in a single year-class from a panmictic population of adult blue rockfish (Sebastes mystinus). Mar Biol 151:451-465

Carr MH, McGinnis MV, Forrester GE, Harding J, Raimondi PT (2003) Consequences of alternative decommissioning options to reef fish assemblages and implications for decommissioning policy. MMS OCS study 2003-053. Coastal Research Center, Santa Barbara, CA

Code of Federal Regulations (2011) Title 50 - Wildlife and Fisheries. Chapter VI: Fishery conservation and management, Sub-part C: West coast groundfish fisheries 660.40. National Oceanic and Atmospheric Administration, US Department of Commerce. Available at http://cfr.vlex. com/source/code-federal-regulations-wildlife-fisheries1099/toc/06.81 (accessed 13 Oct 2011)

> Crowder LB, Cooper WE (1982) Habitat structural complexity and the interaction between bluegills and their prey. Ecology 63:1802-1813

DLCD (Department of Land Conservation and Development) (1987) The Oregon estuary plan book. Available at www.inforain.org/oregon-estuary/ (accessed 15 March 2010)

Edgar GJ, Barrett NS, Graddon DJ, Last PR (2000) The conservation significance of estuaries: a classification of Tasmanian estuaries using ecological, physical, and demographic attributes as a case study. Biol Conserv 92: 383-397

Gallagher MB, Heppell SS (2010) Essential habitat identification for age-0 rockfish along the central Oregon coast. Mar Coast Fish 2:60-72

Gilbert-Horvath EA, Larson RJ, Garza JC (2006) Temporal recruitment patterns and gene flow in kelp rockfish (Sebastes atrovirens). Mol Ecol 15:3801-3815
Gillanders BM (2005) Using elemental chemistry of fish otoliths to determine connectivity between estuarine and coastal habitats. Estuar Coast Shelf Sci 64:47-57

Hedgecock D (1994) Does variance in reproductive success limit effective population sizes of marine organisms? In: Beaumont AR (ed) Genetics and evolution of aquatic organisms. Chapman \& Hall, London, p 122-134

> Hickey BM, Banas NS (2003) Oceanography of the US Pacific Northwest coastal ocean and estuaries with application to coastal ecology. Estuaries 26:1010-1031

Hixon MA, Beets JP (1989) Shelter characteristics and Caribbean fish assemblages: experiments with artificial reefs. Bull Mar Sci 44:666-680

Hyde JR, Vetter RD (2007) The origin, evolution, and diversification of rockfishes of the genus Sebastes (Cuvier). Mol Phylogenet Evol 44:790-811

Ivanova NV, Dewaard JR, Hebert PD (2006) An inexpensive, automation-friendly protocol for recovering high-quality DNA. Mol Ecol Notes 6:998-1002

Johansson ML, Banks MA, Glunt KD, Hassel-Finnegan HM, Buonaccorsi VP (2008) Influence of habitat discontinuity, geographical distance, and oceanography on fine-scale population genetic structure of copper rockfish (Sebastes caurinus). Mol Ecol 17:3051-3061

Johnson DW (2007) Habitat complexity modifies postsettlement mortality and recruitment dynamics of a marine fish. Ecology 88:1716-1725

Kline JD, Azuma DL, Moses A (2003) Modeling the spatially dynamic distribution of humans in the Oregon (USA) coast range. Landsc Ecol 18:347-361

Laidig TE, Chess JR, Howard DF (2007) Relationship between abundance of juvenile rockfishes (Sebastes spp.) and environmental variables documented off the northern California and potential mechanisms for the covariation. Fish Bull 105:39-48

Larson RJ, Lenarz WH, Ralston S (1994) The distribution of pelagic juvenile rockfish of the genus Sebastes in the upwelling region off central California. Calif Coop Ocean Fish Invest Rep 35:177-221

> Lotze HK, Lenihan HS, Bourque BJ, Bradbury RH and others (2006) Depletion, degradation, and recovery potential of estuaries and coastal seas. Science 312:1806-1809

Love MS (1996) Probably more than you want to know about fishes of the Pacific coast, 2nd edn. Really Big Press, Santa Barbara, CA

> Love MS, Carr MH, Haldorson LJ (1991) The ecology of substrate-associated juveniles of the genus Sebastes. Environ Biol Fishes 30:225-243

Love MS, Yoklavich M, Thorsteinson L (2002) The rockfishes of the northeast Pacific. University of California Press, Berkeley, CA

MacNally R, Thomson JR, Kimmerer WJ, Feyrer F and others (2010) Analysis of pelagic species decline in the upper San Francisco estuary using multivariate autoregressive modeling (MAR). Ecol Appl 20:1417-1430

Matarese AC, Kendell AW, Blood DM, Vitner BM (1989) Laboratory guide to early life history stages of Northeast Pacific fishes. Tech Rep NMFS 80. National Oceanic and Atmospheric Administration, Seattle, WA

Miller JA, Shanks AL (2004) Ocean-estuary coupling in the Oregon upwelling region: abundance and transport of juvenile fish and of crab megalopae. Mar Ecol Prog Ser 271:267-279

Miller JA, Shanks AL (2005) Abundance and distribution of larval and juvenile fish in Coos Bay, Oregon: time-series 
analysis based on light-trap collections. Mar Ecol Prog Ser 305:177-191

Monaco ME, Lowery TA, Emmett RL (1992) Assemblages of U.S. west coast estuaries based on the distribution of fishes. J Biogeogr 19:251-267

Najjar RG, Pyke CR, Adams MB, Breitburg D and others (2010) Potential climate-change impacts on the Chesapeake Bay. Estuar Coast Shelf Sci 86:1-20

Parker SJ, Berkeley SA, Golden JT, Gunderson DR and others (2000) Management of Pacific rockfish. Fisheries 25:22-29

Pastén GP, Katayama S, Omori M (2003) Timing of parturition, planktonic duration, and settlement patterns of the black rockfish, Sebastes inermis. Environ Biol Fishes 68: 229-239

Pearcy WG, Myers SS (1974) Larval fishes of Yaquina Bay, Oregon: a nursery ground for marine fishes. Fish Bull 72: 201-213

Ralston S, Howard DF (1995) On the development of yearclass strength and cohort variability in two northern California rockfishes. Fish Bull 93:710-720

Roberts CM, Hawkins JP (1999) Extinction risk at sea. Trends Ecol Evol 14:241-246

Rocha-Olivares A, Kimbrell CA, Eitner BJ, Vetter RD (1999) Evolution of a mitochondrial cytochrome $b$ gene sequence in the species-rich genus Sebastes (Teleostei, Scorpaenidae) and its utility in testing the monophyly of the subgenus Sebastomus. Mol Phylogenet Evol 11:426-440

Rooper CN, Gunderson DR, Armstrong DA (2006) Evidence for resource partitioning and competition in nursery estuaries by juvenile flatfish in Oregon and Washington. Fish Bull 104:616-622

Sakuma KM, Ralston S, Wespestad VG (2006) Interannual

Editorial responsibility: Nicholas Tolimieri,

Seattle, Washington, USA and spatial variation in the distribution of young-of-theyear rockfish (Sebastes spp.): expanding and coordinating a survey sampling frame. Calif Coop Ocean Fish Invest Rep 47:127-139

Sampson DB (2007) The status of black rockfish off Oregon and California in 2007. SAFE documents: October 2008. Available at www.pcouncil.org/groundfish/ stock-assessments/safe-documents/october-2008-safedocument/ (accessed 14 March 2010)

Schlosser S, Bloeser J (2006) The collaborative study of juvenile rockfish, cabezon, and kelp greenling habitat associations between Morro Bay, California and Newport, Oregon. California Sea Grant \& Pacific Marine Conservation Council, Arcata, CA

Seitz RD, Dauer DM, Llanso RJ, Long WC (2009) Broad-scale effects of hypoxia on benthic community structure in Chesapeake Bay, USA. J Exp Mar Biol Ecol 381:S4-S12

Sommer T, Armor C, Baxter R, Breuer R and others (2007) The collapse of pelagic fishes in the upper San Francisco estuary. Fisheries 32:270-277

Studebaker RS, Mulligan TJ (2008) Temporal variation and feeding ecology of juvenile Sebastes in rocky intertidal tidepools of northern California, with emphasis on Sebastes melanops Girard. J Fish Biol 72:1393-1405

Taylor CA, Watson W, Chereskin T, Hyde J, Vetter J (2004) Retention of larval rockfishes, Sebastes, near natal habitat in the Southern California Bight, as indicated by molecular identification methods. Calif Coop Ocean Fish Invest Rep 45:152-166

Wilson JR, Broitman BR, Caselle JE, Wendt DE (2008) Recruitment of coastal fishes and oceanographic variability in central California. Estuar Coast Shelf Sci 79: 483-490

Submitted: March 11, 2011; Accepted: November 15, 2011

Proofs received from author(s): February 7, 2012 